\title{
Nutrient digestibility in Arctic fox (Vulpes lagopus) fed diets containing animal meals
}

[Digestibilidade dos nutrientes em raposa polar (Vulpes lagopus) alimentada com dietas que continham farinhas de origem animal]

\author{
A. Gugotek ${ }^{1}$, W. Zablocki ${ }^{1}$, D. Kowalska ${ }^{2}$, P. Janiszewski ${ }^{1}$, M. Konstantynowicz ${ }^{1}$, J. Strychalski ${ }^{1}$ \\ ${ }^{1}$ University of Warmia and Mazury in Olsztyn \\ Fur-Bearing Animal Breeding and Game Management \\ Oczapowskiego 5/365, 10-719 - Olsztyn, Poland \\ ${ }^{2}$ National Research Institute of Animal Production - Krakowska - Balice, Poland
}

\begin{abstract}
Three digestibility experiments on Arctic foxes were carried out. Control groups were fed standard diets (C1 and $\mathrm{C} 2$ ) composed of fresh or frozen animal by-products and steamed ground grain. Dry experimental diets (E1 and E2) contained animal meals, extracted meals and fat, were mixed with water prior to administration. In a preliminary experiment, the digestibility of dry diet E1 moistened with water for $15 \mathrm{~min}$ and $24 \mathrm{~h}$ was compared to determine the optimum moistening time during the experimental period proper. The preliminary experiment showed that moistening time had no significant effect on digestibility. In the main experiment, two independent digestibility trials were performed to compare the digestibility of diets fed to foxes during growth (C1 vs. E1) and fur development (C2 vs. E2). Better nutrient digestibility was noted for control diets, compared to experimental. The greatest differences were reported for total protein digestibility. Protein contained in meals undergoes denaturation during heat treatment, which reduces digestibility. It was found that the retention of nitrogen in relation to nitrogen digestion was higher in foxes fed experimental diets (E1 and E2).
\end{abstract}

Keywords: Vulpes lagopus, feeding, digestibility, animal meal

\section{RESUMO}

Realizaram-se três ensaios de digestibilidade em raposas polares. Os grupos controles receberam dietaspadrão ( $C 1$ e C2) compostas por subprodutos de origem animal frescos ou congelados e sementes de cereais em grão. As dietas secas (E1, E2) usadas nos ensaios que continham farinha de origem animal e sementes em grãos extrudadas eram hidratadas antes de administradas. Em ensaio preliminar, avaliouse a digestibilidade da dieta seca E1, submetida a 15 minutos e a 24 horas de hidratação. Verificou-se que o tempo de hidratação não influenciou a digestão. No experimento principal, foram realizados dois ensaios para comparar a digestibilidade das dietas fornecidas às raposas no período de crescimento (Cl vs E1) e no desenvolvimento de pelo (C2 vs E2). Melhor digestibilidade dos nutrientes foi observada para as dietas controle. As maiores diferenças foram relatadas para a proteína total. A desnaturação das proteínas, durante o tratamento térmico, reduz o indice de digestibilidade das dietas. Observou-se alto teor de retenção de hidrogênio em relação ao hidrogênio digerido nas raposas alimentadas com as dietas E1 e E2.

Palavras-chave: Vulpes lagopus, alimentação, digestibilidade, farinha de origem animal

Recebido em 23 de novembro de 2009

Aceito em 2 de agosto de 2010

E-mail: gugolek@uwm.edu.pl 


\section{INTRODUCTION}

Carnivorous fur-bearing animals are usually fed conventional wet diets composed of raw animal by-products. Complete mixed feeds containing animal meals, in the form of dry pellets, are also becoming increasingly popular, but they are fed primarily to mink (Laplante, 1987; Zou et al., 1997; Kulikov and Bakakiriev, 2004) and only sporadically to foxes. Research results show that the pelts of foxes fed pelleted feed are high in quality, but smaller in size (Weiss, 1987; Lorek et al., 1999, 2002), which is most probably related to body water balance disorders and pellet falling out through the openings in net wire fences.

Dry feed in friable form, mixed with water prior to administration to obtain the desired consistency of conventional feed, combines the advantages of wet diets and dry pellets. It is cheaper than pellets, can be formulated and prepared on the farm, and offered from traditional feeders (Sławoń, 1991; Gugołek et al., 2007).

Overall feed quality should be evaluated based on both the values of production indicators and the results of digestibility/balance studies. In foxes, the digestion process requires the presence of enzymes (Oleinik, 1995; Szymeczko and Burlikowska, 1996). A comparative analysis of nutrient digestibility in Arctic foxes has been performed, among others, by Ahlstrom and Skrede (1995, 1998), Szymeczko (2001), Ahlstrom et al. (2003), and Vhile et al. (2005a).

The objective of the present study was to determine, based on the results of digestibility/balance trials, whether Arctic foxes can be fed dry diets containing animal meals moistened with water. The effect of moistening time on nutrient digestibility was also analyzed.

\section{MATERIAL AND METHODS}

The experimental materials comprised 10 clinically healthy female Arctic blue foxes, averaging four-month-old. The animals were randomly selected from four litters, and were distributed into two equal groups, one individual from each litter per group $(n=5)$. All animals had similar average body weights. Foxes were placed in individual metabolism cages equipped for separate quantitative collection of feces and urine, in an experimental unit at the University of Warmia and Mazury in Olsztyn, Poland. The trial was conducted from September to October. A 5-day experimental period proper was preceded by a 10-day adjustment period so that the animals could adapt to different environmental and feeding conditions.

The experimental factor was the type of mixed feed offered to foxes. Control group (C) animals were fed standard mixed feed composed of typical ingredients. Dry experimental diets (E) contained animal meals, plant-origin ingredients, fat, vitamin and mineral supplements, and were mixed with water prior to administration (Table 1). The diets had a pulpy consistency and could be offered in traditional feeders. During moistening, diets E1 and E2 absorbed $60 \%$ water. Following water addition, $2.2 \mathrm{~kg}$ moistened feed was obtained from $1 \mathrm{~kg}$ dry feed. The same vitamin and mineral supplements $(1 \mathrm{~kg} / \mathrm{t})$ and sodium metabisulfite $(1 \mathrm{~kg} / \mathrm{t})$ were added to the diets.

Diet composition varied, so as to meet the changing nutrient requirements of foxes. Diets $\mathrm{C} 1$ and E1 were offered at the growth stage (July-September) and diets C2 and E2 at the fur development stage (October-November). Table 2 presents the nutritional and energy values of diets $\mathrm{C} 1, \mathrm{E} 2, \mathrm{C} 2$, and $\mathrm{E} 2$, calculated based on their chemical composition, which was comparable in both groups and fulfilled the nutrient requirements of growing foxes (Nutrient..., 1982; Barabasz et al., 1994).

At the preliminary stage of experiment 1 , the digestibility of dry diet E1 moistened with water for $15 \mathrm{~min}$ and $24 \mathrm{~h}$ was compared to determine the optimum moistening time during the experimental period proper. In the experimental period proper, two digestibility/balance trials (2 and 3) were performed to compare the digestibility of diets fed to foxes during growth (C1 vs. E1) and fur development (C2 vs. E2). Experimental diets were moistened with water for $5 \mathrm{~h}$ before administration. 
Table 1. Composition of diets (\%)

\begin{tabular}{lcccc}
\hline \multirow{2}{*}{ Component } & \multicolumn{3}{c}{ Diets } \\
\cline { 2 - 5 } & $\mathrm{C} 1$ & $\mathrm{C} 2$ & $\mathrm{E} 1$ & $\mathrm{E} 2$ \\
\hline Hard poultry offal & 23.7 & 25.6 & - & - \\
Poultry meat & 19.8 & 17.0 & - & - \\
Soft poultry offal & 17.2 & 19.2 & - & - \\
Mixed poultry offal & 17.0 & 15.3 & - & - \\
Beef offal & 2.3 & 2.0 & - & - \\
Dry ground wheat* & 18.7 & 19.6 & 33.0 & 36.0 \\
Green forage, vegetables & 1.3 & 1.3 & - & - \\
Poultry meal & - & - & 38.0 & 30.0 \\
Blood and feather meal & - & - & 10.0 & 15.0 \\
Fish meal & - & - & 5.0 & 3.0 \\
Poultry fat & - & - & 5.0 & 6.0 \\
Soybean oil & - & - & 5.0 & 6.0 \\
Dry whey & - & - & 2.0 & 2.0 \\
Alfalfa meal & - & - & 2.0 & 2.0 \\
Vitamin and mineral supplements and sodium metabisulfite & $1 \mathrm{~kg} / \mathrm{t}$ & $1 \mathrm{~kg} / \mathrm{t}$ & $1 \mathrm{~kg} / \mathrm{t}$ & $1 \mathrm{~kg} / \mathrm{t}$ \\
\hline * diets C1 and C2 contained steamed ground grain, diets E1 and E2 contained extracted meals. In diets C1 and C2, \\
water accounted for 25\% of dry feed weight (including water used for steaming and water mixed with feed). In diets \\
E1 and E2, water accounted for 60\% of dry feed weight. & & & &
\end{tabular}

Table 2. Nutritive values of diets (calculated on chemical composition)

\begin{tabular}{lcccc}
\hline \multirow{2}{*}{ Specificaion } & \multicolumn{3}{c}{ Diets } \\
\cline { 2 - 5 } & $\mathrm{C} 1$ & $\mathrm{E} 1$ & $\mathrm{C} 2$ & E2 \\
\hline Digestible components g/kg: & & & & 109 \\
protein & 100 & 115 & 107 & 80 \\
fat & 64 & 75 & 75 & 80 \\
carbohydrates & 58 & 71 & 57 & 6,537 \\
\hline Metabolizable energy (MJ/kg) & 5,368 & 6,300 & 5,910 & 31 \\
\hline Energy (\%): & 35 & 34 & 31 & 48 \\
protein & 46 & 46 & 48 & 21 \\
fat & 19 & 20 & 21 & 17 \\
carbohydrates & 19 & 18 & 17 & \\
\hline Protein-energy ratio (g/MJ) & &
\end{tabular}

The animals were fed once daily $(600 \mathrm{~g}$ feed) at the same time, and had free access to water. Leftovers and feces were daily collected, and were weighed accurate to $1 \mathrm{~g}$. Frozen feces samples and feed samples were partially dried and ground. Urine was preserved with $20 \%$ sulfuric acid, and at the completion of the exact experiment, the volume of the entire collection was measured. The samples were transported to the laboratory at the Department of Animal Nutrition and Feed Science, University of Warmia and Mazury in Olsztyn, Poland, to determine their chemical composition and energy value. The nutrient content of feed and feces and the nitrogen content of urine were determined by the Weenden method (Official..., 1990). Nutrient digestibility and nitrogen retention were determined by standard methods (Gugołek et al., 1997; Dahlman et al., 2002; Ahlstrom et al., 2003; Matusevicius et al., 2004). The apparent digestibility (AD) of nutrients was calculated as follows: $\mathrm{AD}=\mathrm{a}-\mathrm{b} / \mathrm{a}$, in which " $\mathrm{a}$ " is nutrient intake from feed and " $b$ " is nutrient excretion in feces.

Data were classified based on a comparative group model, including litters as a block and were verified by F-test (Statistica PL 8.0/2007 StatSoft, Inc.). 


\section{RESULTS AND DISCUSSION}

Table 3 presents the results of three digestibility trials. In experiment 1 , the digestibility of nutrients and energy from diet E1 moistened with water for a different period of time was compared. This experiment showed that moistening time had no statistically significant effect on the digestibility of nutrients and energy contained in the analyzed feed. However, when the feed was moistened for a longer time prior to administration, the digestibility coefficients were slightly higher, i.e. by 1.3 for protein, 0.3 for crude fat, 1.3 for crude fiber, and $4.1 \%$ for $\mathrm{N}$ free extractives. Therefore, the diets fed to animals during successive experiments were moistened for $5 \mathrm{~h}$, which also contributed to better work organization on the farm.

Table 3. Coefficients of nutrient and energy digestibility (\%) in foxes - $(\mathrm{x} \pm \mathrm{s})$

\begin{tabular}{|c|c|c|c|c|c|c|}
\hline \multirow{3}{*}{ Specification } & \multicolumn{6}{|c|}{ Experiments/Diets } \\
\hline & \multicolumn{2}{|c|}{1} & \multicolumn{2}{|c|}{2} & \multicolumn{2}{|c|}{3} \\
\hline & E1-15 & E1-24 & C1 & E1 & $\mathrm{C} 2$ & E2 \\
\hline Number of animal & 5 & 5 & 5 & 5 & 5 & 5 \\
\hline Dry matter & $70.0 \pm 1.7$ & $70.8 \pm 2.5$ & $81.3 \pm 2.5^{* *}$ & $72.7 \pm 2.5 * *$ & $78.2 \pm 3.5 * *$ & $68.9 \pm 1.0 * *$ \\
\hline Organic matter & $72.2 \pm 3.0$ & $74,1 \pm 2.8$ & $87.1 \pm 2.6^{* *}$ & $76.6 \pm 2.6 * *$ & $84.5 \pm 1.1 * *$ & $71.8 \pm 1.1^{* *}$ \\
\hline Crude protein & $65.7 \pm 6.6$ & $67.0 \pm 4.0$ & $88.6 \pm 3.8 * *$ & $67.4 \pm 3.8 * *$ & $84.9 \pm 5.7 * *$ & $61.4 \pm 5.9 * *$ \\
\hline Crude fat & $92.9 \pm 0.8$ & $93.2 \pm 0.9$ & $96.7 \pm 0.5 * *$ & $94.2 \pm 0.5 * *$ & $95.9 \pm 0.5 * *$ & $92.9 \pm 0.5^{* *}$ \\
\hline Crude fiber & $20.5 \pm 1.9$ & $21.8 \pm 1.5$ & $29.1 \pm 2.0$ & $24.4 \pm 2.0$ & $27.9 \pm 3.4$ & $22.2 \pm 3.4$ \\
\hline $\mathrm{N}$-free extract & $77.9 \pm 5.9$ & $82.0 \pm 5.7$ & $75.2 \pm 2.3$ & $77.1 \pm 2.3$ & $75.8 \pm 0.8$ & $77.2 \pm 0.8$ \\
\hline Gross energy & $75.6 \pm 2.4$ & $77.5 \pm 3.0$ & $89.3 \pm 2.0 * *$ & $79.2 \pm 2.0 * *$ & $87.1 \pm 1.2 * *$ & $74.5 \pm 1.1 * *$ \\
\hline
\end{tabular}

In experiments 2 and 3 , the digestibility of control (C1, C2) and experimental (E1, E2) diets was compared. Diets $\mathrm{C} 1$ and $\mathrm{C} 2$ were characterized by better nutrient digestibility than diets E1 and E2. Highly significant differences were observed in respect of dry matter, organic substances, total protein, total fat, and gross energy. Smaller differences were noted for carbohydrates, due to the specificity of the digestion processes in carnivores (Oleinik, 1995). The greatest differences were reported for total protein digestibility, reaching $21.2 \%$ between diets $\mathrm{C} 1$ and $\mathrm{E} 1$ in experiment 2, and $23.5 \%$ between diets $\mathrm{C} 2$ and E2 in experiment 3. This resulted from the fact that protein contained in meals undergoes denaturation during heat treatment, which reduces digestibility. It seems interesting that total protein digestibility was lower in diet E2 than in diet E1. The presence of keratin found in the feathers, crude ash, bones, and crude fiber, and high levels of vegetable protein in the ration contribute to a decrease in total protein digestibility. As regards diet E2, the reason for lower protein digestibility could be a higher content of blood and feather meal. Feather meal, produced by hydrolyzing feathers, contains high concentrations of poorly assimilable protein. However, this kind of meal is a valuable component of diets fed to animals during fur development, due to a high content of sulfur amino acids (Zoń et al., 2000).

Ahlstrom et al. (2000) and Vhile et al. (2005b) also observed lower protein digestibility for diets containing meat meal. The digestibility coefficient of protein contained in standard mixed feed for foxes ranges from 78 to $86 \%$, and usually exceeds $80 \%$ (Dahlman et al., 2002; Ahlstrom et al., 2003; Vhile et al., 2005b).

The differences in fat digestibility between the groups reached 2.5 and $3.0 \%$. Fat utilization is generally high in fur-bearing animals, particularly with respect to unsaturated fatty acids found, among others, in raw poultry offal, poultry meals, and fat. Also in the studies conducted by Dahlman et al. (2002) and Ahlstrom et al. (2003), fat digestibility coefficients exceeded 90\%. Gross energy digestibility was higher in the experimental group, which resulted from higher digestibility of individual nutrients. The values of digestibility coefficients, previously presented, can be considered typical of growing Arctic foxes aged four to five months, despite statistically significant differences between the control and experimental groups. These results are also consistent with the findings of other authors, 
regarding Arctic foxes (Ahlstrom and Skrede, 1995, 1998; Gugołek et al., 1997; Lorek et al., 1999, 2002; Ahlstrom et al., 2000; Szymeczko, 2001; Dahlman et al., 2002; Matusevicius et al., 2004; Vhile et al., 2005a,b).

Table 4 shows daily balance and retention of nitrogen. The retention of digested nitrogen in relation to nitrogen intake was higher in the control group, although the observed differences were statistically non-significant. An opposite trend was noted for nitrogen retention in relation to nitrogen digestion. The differences between diets $\mathrm{C} 1$ and $\mathrm{E} 1$, and $\mathrm{C} 2$ and $\mathrm{E} 2$ reached $7.2 \%$ and $10.3 \%$ respectively. Of particular note, is the higher level of nitrogen retention in relation to nitrogen digestion in foxes fed experimental diets
(E1 and E2). This could be a consequence of better utilization of protein contained in meals, resulting from a more desirable amino acid composition of experimental diets. However, further investigations are needed to verify this hypothesis. In a previous study (Gugołek et al., 1997), there were no statistically significant differences in nitrogen retention between conventional feed and dry pellets. In an experiment performed by Dahlman et al. (2002), nitrogen retention relative to nitrogen intake ranged from 14.1 to 29.2 and from 16.3 to $27.7 \%$, while nitrogen retention in relation to nitrogen digestion - from 17.0 to 37.0 and from 19.8 to $36.7 \%$. Similar values regarding nitrogen retention were reported by Matusevicius et al. (2004).

Table 4. Daily nitrogen balance $(\mathrm{g})$ and retention $(\%)-(\mathrm{x} \pm \mathrm{s})$

\begin{tabular}{|c|c|c|c|c|}
\hline \multirow{3}{*}{ Nitrogen (g/animal) } & \multicolumn{4}{|c|}{ Experiments/Diets } \\
\hline & \multicolumn{2}{|c|}{2} & \multicolumn{2}{|c|}{3} \\
\hline & $\mathrm{C} 1$ & E1 & $\mathrm{C} 2$ & E2 \\
\hline Number of animals & 5 & 5 & 5 & 5 \\
\hline Intake & $9.4 \pm 0.03 * *$ & $12.9 \pm 0.03 * *$ & $13.9 \pm 0.04 * *$ & $18.0 \pm 0.04 * *$ \\
\hline Excretion in feces & $1.1 \pm 0.3 * *$ & $4.2 \pm 0.3 * *$ & $2.1 \pm 0.4 * *$ & $7.4 \pm 0.4 * *$ \\
\hline Excretion in urine & $5.7 \pm 0.3 *$ & $5.3 \pm 0.3 *$ & $7.9 \pm 0.5^{*}$ & $5.9 \pm 0.5 *$ \\
\hline Digestion & $8.3 \pm 0.7$ & $8.7 \pm 0.7$ & $11.9 \pm 0.3 *$ & $10.7 \pm 0.3 *$ \\
\hline Retention & $2.6 \pm 0.4 *$ & $3.4 \pm 0.4 *$ & $3.9 \pm 0.5$ & $4.7 \pm 0.5$ \\
\hline Retention in relation to $\mathrm{N}$ intake $\%$ & $27.9 \pm 2.9$ & $26.1 \pm 2.9$ & $28.6 \pm 3.0$ & $25.9 \pm 3.0$ \\
\hline Retention in relation to $\mathrm{N}$ digestion $\%$ & $31.4 \pm 3.8$ & $38.6 \pm 3.8$ & $33.6 \pm 4.1 *$ & $43.9 \pm 4.1 *$ \\
\hline
\end{tabular}

** $\mathrm{P}<0.01 ; * \mathrm{P}<0.05$

\section{CONCLUSION}

The results of this research indicate that standard traditional diets are characterized by better nutrient digestibility, compared to dry experimental diets moistened with water prior to administration. Although both types of diets had a similar nutritional value, highly significant digestibility differences were observed in respect of dry matter, organic substances, total protein, total fat, and gross energy. Furthermore, the retention of digested nitrogen in relation to nitrogen intake was higher in the control group and an opposite trend was noted for nitrogen retention in relation to nitrogen digestion. In summarizing the results obtained, it is concluded that farmed Arctic foxes should be still fed traditional prepared diets.

\section{REFERENCES}

AHLSTROM, O.; SKREDE, A. Comparative nutrient digestibility in blue foxes (Alopex lagopus) and mink (Mustela vison) fed diets with diverging fat: carbohydrate ratios. Acta Agric. Scand. Section A, Anim. Sci., v.45, p.74-80, 1995.

AHLSTROM, O.; SKREDE, A. Comparative nutrient digestibility in dog, blue fox, mink and rat. J. Nutr., v.128, p.2676-2677, 1998.

AHLSTROM, O.; SKREDE, A.; HEGEST, O. et al. Meat and bone meals from different animal by products as protein sources for fur animals. Scientifur, v.24, p.63-66, 2000.

AHLSTROM, O.; FUGLEI, E.; MYDLAND, L. Comparative nutrient digestibility of arctic foxes (Alopex lagopus) on Svalbald and farm-raised fox (Alopex lagopus). Comp. Bioch. Physiol. Part A., v.134, p.63-68, 2003. 
BARABASZ, B.; BIELAŃSKI, P.; NIEDŹWIADEK, $\mathrm{S}$. et al. Nutrient requirements of carnivorous and herbivorous fur-bearing animals. Nutritional value of feed (in Polish). Jabłonna, Poland: Polish Academy of Sciences, Institute of Animal Physiology and Nutrition, 1994.

DAHLMAN, T.; KIISKINEN, T.; MAKELA, J. et al. Digestibility and nitrogen utilization of diets containing protein at different levels and supplemented with DL-methioninine, Lmethionine and L-lisine in blue fox (Alopex lagopus). Anim. Feed Sci. Tech., v.98, p.219-235, 2002.

GUGOŁEK, A.; LOREK, M.O;; GRZECHNIK, M. et al. Nutrient digestibility and nitrogen retention in Arctic foxes fed dry pellets. Acta Acad. Agricult. Tech. Olst. Zootech., v.47, p.4148, 1997.

GUGOŁEK, A.; LOREK, M.O.; ROTKIEWICZ, Z. et al. Microbiological condition of complete friable diet and the affect on reproduction results of polar foxes. Rocz. Nauk. PTZ., v.3, p.237-244, 2007.

KULIKOV, N.; BALAKIRIEV, N. The importance of protein for young minks fed with dry food. Scientiur, v.3, p.147-149, 2004.

LAPLANTE, J. Comparison of 3 feeding systems for growing-furring mink: conventional vs. semi-complete vs. pelleta. Scientifur, v.2, p.139, 1987.

LOREK, M.O.; GUGOŁEK, A.; HARTMAN, A. Effect of feed pellets to arctic foxs on their performance and selected morphologicalbiochemical blood indices. Czech J. Anim. Sci., v.47, p.333-338, 2002.

LOREK, M.O.; GUGOŁEK, A.; ROTKIEWICZ, T. et al. Pelleted feed for arctic fox. Czech J. Anim. Sci., v.11, p.503-507, 1999.

MATUSEVICIUS, P.; JANUSKIEVICIUS, A.; GUGOŁEK, A.; ZILINSKIENE, A. The effect of use of synthetic methionine in fox (Alopex lagopus L.). Vet. Zootech., v.25, p.71-75, 2004.
NUTRIENT requirements of mink and foxes. Washington, DC: National Research Council, Academy Press, 1982.

OFFICIAL methods of analysis. 15.ed. Arlington: AOAC, 1990.

OLEINIK, V.M. Distribution of digesttive enzyme activities along intestine in blue fox, mink, ferret and rat. Comp. Biochem. Physiol., v.112A, p.55-58, 1995.

SKREDE, A.; GULBRAMDSEN, K. Fat sources in pelleted dry diets for mink and foxes. Scientifur, v.1, p.81-83, 1986.

SŁAWON,, J. Studies on the composition of friable and pelleted complete diets for Arctic foxes. Zesz. Nauk. Przegl. Hod., v.5, p.152-165, 1991.

SZYMECZKO, R. Ileal and total digestibility of amino acids in feeds used in mink and polar fox nutrition. J. Anim. Feed Sci., v.10, Suppl. 1, p.211-222, 2001.

SZYMECZKO, R.; BURLIKOWSKA, K. Protein digestion in the digestive tract of polar foxes. Scientifur, v.20, p.203-208, 1996.

VHILE, S.G.; SKREDE, A.; AHLSTROM, O. et al. Comparative apparent total tract digestibulity of major nutrients and amino acids in dogs (Canis familiaris), blue foxes (Alopex lagopus) and mink (Mustela vison). Anim. Sci., v.81, p.141-148, 2005a.

VHILE, S.G.; SKREDE, A.; AHLSTROM, O. et al. Ileal and total tract nutrient digestibility in blue fox (Alopex lagopus) fed extruded diets containing different protein sources. Arch. Anim. Nutr., v.59, p.61-72, 2005 b.

WEISS, V. Trockenfutter. Der Deutsche Pelztierzuchter, v.7, p.97-98, 1987.

ZOŃ, A.; SŁAWOŃ, J.; BIELAŃSKI, P. et al. Effect of the nutrition regime on pelt quality in Arctic blue foxes. Rocz. Nauk. Zoot., v.6, suppl., p.312-317, 2000.

ZOU, X.; HAN, Y.; ZHU, Z. Mixed pelleted feeding in mink. J. Econom. Anim., v.1, p.7-10, 1997. 